\title{
Perfil de fermentação e perdas na ensilagem de diferentes frações da parte aérea de quatro variedades de mandioca ${ }^{1}$
}

\section{Álvaro Diego Soares Mota², Vicente Ribeiro Rocha Júnior ${ }^{3,4}$, André Santos de Souza $^{5}$, Sidnei Tavares dos Reis ${ }^{3,6}$, Thierry Ribeiro Tomich ${ }^{7}$, Luciana Albuquerque Caldeira ${ }^{3,6}$, Gustavo Chamon de Castro Menezes ${ }^{8}$, Maria Dulcinéia da Costa ${ }^{3,6}$}

\author{
1 Projeto financiado pela FAPEMIG. \\ 2 Programa de Pós-Graduação em Produção Vegetal no Semiárido/UNIMONTES. \\ 3 Departamento de Ciências Agrárias/Zootecnia/UNIMONTES. \\ ${ }^{4}$ Bolsista de Produtividade em Pesquisa do CNPq. \\ 5 Programa de Pós-Graduação em Zootecnia/UNIMONTES. \\ ${ }^{6}$ Bolsista de Produtividade em Pesquisa da FAPEMIG. \\ ${ }^{7}$ EMBRAPA Pantanal, Corumbá/MS. \\ ${ }^{8}$ Programa de Pós-Graduação em Zootecnia/UFV.
}

RESUMO - Objetivou-se com este trabalho determinar o perfil fermentativo das silagens de quatro variedades de mandioca. No estudo do pH, do nitrogênio amoniacal, dos ácidos orgânicos, do índice de recuperação de matéria seca (MS) e da densidade das silagens, utilizou-se delineamento em blocos casualizados com esquema fatorial $4 \times 3$, com quatro repetições, sendo quatro variedades de mandioca (Amarelinha, Olho Roxo, Periquita e Sabará) e três frações da parte aérea (planta inteira, sobras do plantio e terço superior). No estudo da perda de matéria seca por gases e efluentes, o esquema fatorial utilizado foi $4 \times 3 \times 7$, com quatro repetições, composto de quatro variedades de mandioca, três frações da parte aérea e sete datas de abertura dos silos (1, 3, 5, 7, 14, 28 e 56 dias após a ensilagem). A ensilagem foi realizada em silos de laboratório confeccionados em tubos de PVC. Os dados obtidos foram submetidos à análise de variância e, para comparação das médias, foi realizado o teste de Scott-Knott a 5\% de significância. Não houve diferença significativa entre os valores de pH, ácidos orgânicos e densidade das silagens das diferentes variedades, entretanto, o pH, o nitrogênio amoniacal e a densidade das silagens das frações da parte aérea diferiram entre as variedades. O nitrogênio amoniacal das silagens também diferiu entre as variedades. Embora a forragem fresca tenha apresentado valores de matéria seca inferiores a 30\%, os valores de $\mathrm{pH}$ foram satisfatórios. As silagens das frações terço superior e sobras do plantio têm ótima qualidade fermentativa. As silagens deste estudo apresentam baixa perda de matéria seca.

Palavras-chave: ácidos orgânicos, densidade de silagem, nitrogênio amoniacal, pH

\section{Fermentation profile and losses in the ensilage of different fractions of the aerial part from four cassava varieties}

\begin{abstract}
The objective of this work was to determine fermentative profile of silage of four cassava varieties. In the study of $\mathrm{pH}$, ammonia nitrogen, organic acid, dry matter (DM) recovery index and silage densities, it was used a $4 \times 3$ factorial arrangement, with four repetitions, four cassava varieties (Amarelinha, Olho Roxo, Periquita and Sabará) and three aerial part fractions (entire plant, surpluses of the planting and superior third). In the study of dry matter loss by gases and effluents, it was used a $4 \times 3 \times 7$ factorial arrangement, with four replicates, composed of four cassava varieties, three aerial section fractions and seven silo opening dates (1, 3, 5, 7, 14, 28 and 56 days after ensilage). Ensilage was done in laboratory silos made of PVC pipes. The obtained data were submitted to analysis of variance and for average comparison effect, the test of Scott-Knott was performed at the $5 \%$ level of significance. There was no significant difference among $\mathrm{pH}$ values, organic acid and silage densities of the different varieties but $\mathrm{pH}$, ammonia nitrogen and silage densities of aerial section fractions differed among varieties. Ammonia nitrogen of silages also differed among varieties. Although fresh forage had presented dry matter values lower than $30 \%$, values of $\mathrm{pH}$ were satisfactory. Silages of superior-third fractions and plant remains present great fermentative quality. Silages of this study present low dry matter loss.
\end{abstract}

Key Words: ammonia-nitrogen, density of silage, organic acids, $\mathrm{pH}$ 


\section{Introdução}

Em regra, a finalidade da lavoura de mandioca na região Norte de Minas Gerais é a subsistência, aliada à comercialização do excedente de raízes. Segundo o IBGE (2008), a produtividade média nacional de raízes é de aproximadamente 14,95 t/ha, média inferior ao potencial da cultura, que, segundo FAO (2007), é de 30 a 60 t/ha para um ciclo de 540 dias.

No sistema tradicional de cultivo praticado pelos produtores, a parte aérea da planta de mandioca é aproveitada apenas para a produção de manivas, empregadas no replantio de novas áreas de cultivo. A parte aérea restante (80 a 90\%) é frequentemente descartada (Nunes Irmão et al., 2008). Dessa forma, a parte aérea da mandioca, que é um alimento volumoso com bom valor nutritivo para os animais ruminantes, especialmente com relação ao elevado teor proteico (Faustino, 2003), não é aproveitada para alimentação dos rebanhos, o que poderia incrementar a produção de leite e carne na região.

O rendimento forrageiro e o valor nutritivo da parte aérea da mandioca são influenciados pela variedade e pela fração da parte aérea utilizada como forragem, assim como pela sua adequação para ensilagem (Azevedo et al., 2006). No Norte de Minas são encontradas variedades de mandioca que se estabeleceram em função da adpatação às condições regionais de cultivo e utilização. Nesta região, são observadas inúmeras variedades de mesa e outras destinadas à produção artesanal de farinha, as quais apresentam reconhecida aceitação pelos produtores. Contudo, o potencial forrageiro, a produtividade de raízes e o valor nutritivo, assim como a adequação para a ensilagem das diferentes frações da parte aérea dessas variedades de mandioca ainda é pouco conhecida.

Alguns estudos (Ferreira et al., 2007; Guedes et al., 2007; Araújo et al., 2009) envolvendo diferentes variedades de mandioca comprovaram que o valor nutricional e a qualidade das silagens produzidas são influenciados tanto pela variedade como pela fração da parte aérea utilizada. Diante do exposto, objetivou-se avaliar a qualidade da fermentação das silagens de três frações da parte aérea de quatro variedades de mandioca cultivadas no Norte de Minas Gerais.

\section{Material e Métodos}

O experimento foi conduzido na Fazenda Experimental da UNIMONTES, localizada no município de Janaúba, Norte de Minas Gerais, no período de 17/12/2007 a 19/8/2008. Utilizou-se o delineamento em blocos casualizados, com esquema fatorial $4 \times 3$, com quatro repetições e quatro variedades de mandioca (Amarelinha, Olho Roxo, Periquita e Sabará) e três frações da parte aérea (planta inteira, terço superior e sobras de plantio), para estudo do pH, do nitrogênio amoniacal, dos ácidos orgânicos, da recuperação de matéria seca e da densidade das silagens. No estudo das perdas de matéria seca por gases e por efluentes, utilizou-se o delineamento em blocos casualizados, com esquema fatorial $4 \times 3 \times 7$, com quatro repetições, composto de quatro variedades de mandioca, três frações da parte aérea e sete datas de abertura do silo (1, 3, 5, 7, 14, 28 e 56 dias após ensilagem).

O plantio das variedades foi realizado nos dias $17 \mathrm{e}$ 18/12/2007, usando espaçamento de 1,0 m entre linhas e 0,75 m entre plantas na linha, totalizando uma população final de 13.333 plantas/ha. A parcela experimental foi constituída de seis linhas de plantio, cada uma com 8,0 m de comprimento, totalizando a área da parcela em $48 \mathrm{~m}^{2}$. Foi realizada a adubação de plantio com fontes de fósforo e potássio de acordo com recomendação de adubação para a cultura (Nogueira \& Gomes, 1999), após verificação da análise do solo. A adubação de cobertura, com fonte de nitrogênio, ocorreu aos 60 dias após a emergência das plântulas. As parcelas foram irrigadas (uma vez por semana) desde o plantio até a colheita, realizada entre os dias 5/8/2008 e 19/8/2008.

Foi estabelecido como momento de colheita aquele em que as raízes apresentavam aceitação por parte dos consumidores, ou seja, quando estavam aptas para o consumo humano, e isso ocorreu aproximadamente aos 8 meses de idade, quando, então, foi feito registro da produção forrageira por hectare. A relação folha/haste foi determinada retirando-se o limbo foliar do restante da planta nas três frações da parte aérea. Amostras das forragens frescas foram submetidas a pré-secagem em estufa a $55^{\circ} \mathrm{C}$ até peso constante, trituradas em moinho de facas com peneira de $1 \mathrm{~mm}$ e analisadas quanto ao teor de proteína bruta, pelo método de Kjeldahl, e matéria seca, conforme metodologia descrita por Silva \& Queiroz (2006).

Para a coleta da forragem, para a produção de silagem, utilizaram-se as quatro linhas centrais de cada parcela, onde foi realizado o corte da parte aérea para determinação do rendimento de forragem fresca da parte aérea total, do terço superior e da parte aérea restante após a retirada das manivas suficientes para o replantio da mesma área. A fração planta inteira foi determinada da seguinte forma: cortou-se a parte aérea total da planta a $20 \mathrm{~cm}$ do solo. A fração terço superior foi determinada como sendo o terço superior da planta. A fração sobras do plantio foi constituída como a parte do caule da planta em que havia a presença de 
folhas, sendo considerada a fração remanescente após a retirada das manivas para o replantio da área.

A forragem de cada parcela foi picada em picadeira estacionária com tamanho médio de partículas de 2,0 cm e manualmente homogeneizada. Em seguida, retirou-se uma subamostra para composição do material original (forragem fresca), que foi acondicionada em saco plástico identificado e congelada em freezer para posterior análise. O restante da forragem foi utilizado para confecção das silagens sem prévio emurchecimento.

A ensilagem foi realizada em silos de laboratório confeccionados em tubos de PVC com $40 \mathrm{~cm}$ de comprimento e $10 \mathrm{~cm}$ de diâmetro, dotados de válvula tipo Bunsen para escape de gases, e câmara de areia para a coleta de efluentes. A forragem picada foi compactada no silo experimental com auxílio de um soquete de madeira visando densidade de $600-800 \mathrm{~kg} / \mathrm{m}^{3}$. De cada parcela experimental, foram confeccionados oito silos, que foram abertos 1, 3, 5, 7, 14, 28 e 56 dias após a ensilagem.

Os valores de $\mathrm{pH}$, nitrogênio amoniacal $\left(\mathrm{N}-\mathrm{NH}_{3}\right)$, ácidos orgânicos (lático, butírico, acético e propiônico) e recuperação de matéria seca foram determinados nas silagens aos 56 dias após a confecção. A silagem foi removida após a pesagem dos silos, homogeneizada, uma parte pré-seca em estufa a $55^{\circ} \mathrm{C}$ até peso constante, conforme metodologia descrita por Silva \& Queiroz (2006), e a outra parte utilizada para extração do suco. O suco da silagem foi extraído com o auxílio de uma prensa hidráulica. Neste suco, imediatamente após a extração, foram determinados os valores de $\mathrm{pH}$, utilizando-se potenciômetro específico, e o conteúdo de $\mathrm{N}-\mathrm{NH}_{3}$, por destilação com óxido de magnésio e cloreto de cálcio, empregando solução receptora de ácido bórico e titulação com ácido clorídrico a 0,1 N. Deste suco $10 \mathrm{~mL}$ foram acondicionados em recipientes contendo $2 \mathrm{~mL}$ da solução com ácido metafosfórico e congelados para avaliação posterior dos teores de ácidos orgânicos (lático, acético, propiônico e butírico), por cromatografia gasosa. $\mathrm{Na}$ silagem pré-seca, foi realizada a secagem definitiva a $105^{\circ} \mathrm{C}$, para determinação da matéria seca total da silagem, conforme Silva \& Queiroz (2006). A densidade das silagens foi determinada após pesagem da massa ensilada nos silos de PVC de dimensões conhecidas.

As análises para determinação dos ácidos orgânicos foram realizadas no Laboratório de Nutrição Animal da Escola de Veterinária da Universidade Federal de Minas Gerais, e as demais análises no Laboratório de Análise de Alimentos da Universidade Estadual de Montes Claros Campus de Janaúba.
As perdas por efluentes foram quantificadas nas silagens 1, 3, 5, 7, 14, 28 e 56 dias, por meio da equação proposta por Jobim et al. (2007):

$E=\left\{\frac{(P a b-P e n)}{M V f e}\right\} x 100$,

em que $\mathrm{E}=$ produção de efluente ( $\mathrm{kg} / \mathrm{t}$ de massa verde); $\mathrm{Pab}=$ peso do conjunto (silo + areia + tela) na abertura $(\mathrm{kg})$; Pen $=$ peso do conjunto $($ silo + areia + tela) na ensilagem (kg); MVfe = massa verde de forragem ensilada (kg).

As perdas por gases foram quantificadas nas silagens $1,3,5,7,14$, 28 e 56 dias, por meio da equação proposta por Mari (2003):

$P G=\left\{\frac{(P S f-P S a)}{(M F f x M S f)}\right\} x 100$,

em que: $\mathrm{PG}=$ perda de gases durante o armazenamento (\% da matéria seca inicial); PSf = peso do silo na ensilagem; $\mathrm{PSa}=$ peso do silo na abertura; $\mathrm{MFf}$ = massa de forragem na ensilagem; MSf = teor de matéria seca da forragem na ensilagem.

O índice de recuperação de matéria seca na silagem aos 56 dias após a confecção foi determinado pelo método proposto por Jobim et al. (2007), segundo a seguinte equação:

$R M S=\left\{\frac{(\text { MFabxMSab })}{(\text { MFfexMSfe })}\right\} \times 100$,

em que: RMS = índice de recuperação de matéria seca; MFab = massa de forragem na abertura; MSab = teor de matéria seca na abertura; MFfe = massa de forragem no fechamento; MSfe = teor de matéria seca da forragem no fechamento.

Todos os dados obtidos foram submetidos à análise de variância utilizando-se o programa estatístico SAEG (Ribeiro Júnior, 2001) e, para efeito de comparação das médias de $\mathrm{pH}, \mathrm{N}-\mathrm{NH}_{3}$, recuperação de matéria seca, ácidos orgânicos e densidade das silagens, foi realizado o teste Scott-Knott com 5\% de significância e, para a perda por gases e por efluentes, foi realizado o estudo de regressão.

\section{Resultados e Discussão}

As variedades que apresentaram os maiores percentuais de matéria seca foram a Sabará e a Amarelinha, e a variedade Sabará também apresentou o maior percentual de nitrogênio amoniacal. Não houve efeito significativo de variedade para os valores de $\mathrm{pH}$ e densidade das silagens $(\mathrm{P}>0,05)$ (Tabela 1). 
A fração da parte aérea utilizada para ensilagem não influenciou $(\mathrm{P}>0,05)$ os teores de matéria seca das respectivas silagens (Tabela 2) e apresentou média de 25,04\% de matéria seca. Entretanto, houve efeito significativo $(\mathrm{P}<0,05)$ das frações da parte aérea sobre o $\mathrm{pH}$, o nitrogênio amoniacal e a densidade da silagem (Tabela 2), sendo que, para as três variáveis, a fração planta inteira apresentou os maiores valores $(\mathrm{P}<0,05)$.

As silagens da parte aérea das quatro variedades de mandioca apresentaram percentual de matéria seca inferior a 30\%, valor de referência para silagens de milho. Esse fato pode ser explicado pela suculência ou alto teor de umidade do material que originou a silagem. No entanto, Oliveira (1984) encontrou valores de 24,19 e $24,15 \%$ de matéria seca para as silagens da parte aérea total e silagem do terço superior da mandioca, respectivamente. Modesto et al. (2004) encontraram percentual de 25,20\% de matéria seca na silagem do terço superior da mandioca e Modesto et al. (2008) 25,64\% de matéria seca na silagem da rama de mandioca, que corresponde à parte aérea total. Valadares Filho et al. (2006) relacionaram valores de matéria seca na silagem da parte aérea da mandioca, silagem da parte aérea da mandioca emurchecida e silagem do terço superior da mandioca, correspondendo a, respectivamente, 25,68; 27,70 e $24,15 \%$ de matéria seca.

As silagens das frações sobras do plantio e terço superior apresentaram médias de $\mathrm{pH}$ próximas à encontrada por Carvalho et al. (2008), que foi de 3,99 para a silagem da parte aérea da mandioca. Já Oliveira (1984) encontrou valor de $\mathrm{pH}$ de 4,04 para a silagem da parte aérea total da mandioca e pH de 4,11 para a silagem do terço superior. As silagens da parte aérea total apresentaram $\mathrm{pH}$ superior ao relatado por Oliveira (1984), para esta fração, no entanto, as silagens do terço superior mostraram valores de $\mathrm{pH}$ inferiores aos relatados por estes autores.

Valadares Filho et al. (2006) relacionam valores de $\mathrm{pH}$ de 4,11; 3,60 e 3,81, respectivamente, para as silagens do terço superior, silagem da parte aérea emurchecida e para a silagem da parte aérea. Os valores de pH encontrados nesse estudo para a silagem do terço superior, foram inferiores, no entanto, as silagens da fração planta inteira apresentaram valores de $\mathrm{pH}$ superiores ao relatado por estes autores.

As silagens das frações sobras do plantio e terço superior apresentaram valores de $\mathrm{pH}$ dentro $(3,8$ a 4,2) dos parâmetros recomendados por McDonald et al. (1991). Segundo esses autores, uma silagem de boa qualidade apresenta valores de pH entre 3,8 e 4,2. Dessa forma, as silagens da fração planta inteira seriam classificadas como de média qualidade, por apresentarem valores de $\mathrm{pH}$ entre 4,2 e 4,5. A diminuição do $\mathrm{pH}$ da silagem a valores próximos a 4,0 auxilia na preservação da silagem, em virtude da inibição da atividade das bactérias do gênero Clostridium, que são responsáveis pela produção do ácido butírico e pela deterioração da silagem. Segundo Faustino (2003), o elevado teor proteico da parte aérea da mandioca pode dificultar a redução do $\mathrm{pH}$ pelo marcado efeito tamponante na forrageira ensilada. Todavia, neste trabalho este efeito não foi constatado, em função dos adequados valores de $\mathrm{pH}$ observados nas silagens do terço superior e sobras do plantio, frações que apresentaram elevados teores de proteína bruta (17,81 e 17,90\%, respectivamente).

Embora a forragem fresca tenha apresentado valores de matéria seca inferiores (20,90 a 25,12\%) ao recomendado para a ensilagem de forrageiras (30 a 35\%, segundo McDonald et al., 1991), as forrageiras proporcionaram silagens com valores de $\mathrm{pH}$ satisfatórios. Provavelmente, os menores

Tabela 1 - Matéria seca, pH, nitrogênio amoniacal e densidade das silagens de quatro variedades de mandioca após 56 dias de ensilagem

\begin{tabular}{lcccc}
\hline Variedade & Matéria seca $(\%)$ & $\mathrm{pH}$ & Nitrogênio amoniacal (\% do N-Total) & Densidade $\left(\mathrm{kg} / \mathrm{m}^{3}\right)$ \\
\hline Amarelinha & $26,15 \mathrm{a}$ & $4,06 \mathrm{a}$ & $1,62 \mathrm{~b}$ & $651,63 \mathrm{a}$ \\
Sabará & $27,10 \mathrm{a}$ & $4,14 \mathrm{a}$ & $2,05 \mathrm{a}$ & $678,02 \mathrm{a}$ \\
Olho Roxo & $21,93 \mathrm{c}$ & $4,07 \mathrm{a}$ & $1,56 \mathrm{~b}$ & $685,02 \mathrm{a}$ \\
Periquita & $24,99 \mathrm{~b}$ & $4,01 \mathrm{a}$ & $1,54 \mathrm{~b}$ & $692,61 \mathrm{a}$ \\
CV (\%) & 6,11 & 5,63 & 23,44 & 6,47 \\
\hline
\end{tabular}

*Médias seguidas de mesma letra na coluna não diferem entre si pelo teste de Scott-Knott (1974) a 5\%. CV = coeficiente de variação.

Tabela 2 - Matéria seca, pH, nitrogênio amoniacal e densidade das silagens de três frações da parte aérea de quatro variedades de mandioca após 56 dias de ensilagem

\begin{tabular}{lcccc}
\hline Fração & MS $(\%)$ & $\mathrm{pH}$ & Nitrogênio amoniacal $(\%$ do $\mathrm{N}$-total) & Densidade $\left(\mathrm{kg} / \mathrm{m}^{3}\right)$ \\
\hline Planta inteira & $25,22 \mathrm{a}$ & $4,30 \mathrm{a}$ & $2,35 \mathrm{a}$ & $702,54 \mathrm{a}$ \\
Sobras do plantio & $25,14 \mathrm{a}$ & $4,03 \mathrm{~b}$ & $1,39 \mathrm{~b}$ & $665,32 \mathrm{~b}$ \\
Terço superior & $24,76 \mathrm{a}$ & $3,91 \mathrm{~b}$ & $1,34 \mathrm{~b}$ & $662,59 \mathrm{~b}$ \\
CV $(\%)$ & 6,11 & 5,63 & 23,44 & 6,47 \\
\hline
\end{tabular}

*Médias seguidas de mesma letra na coluna não diferem entre si pelo teste de Scott-Knott (1974) a 5\%. CV = coeficiente de variação. 
valores de $\mathrm{pH}$ verificados nas silagens do terço superior e das sobras do plantio, em relação à silagem da planta inteira foram decorrentes das maiores concentrações de carboidratos solúveis nessas frações.

Os valores de nitrogênio amoniacal encontrados neste estudo permitem classificar essas silagens como de ótima qualidade, uma vez que, de acordo com McDonald et al. (1991), uma silagem de ótima qualidade deve apresentar menos de $10 \%$ de nitrogênio amoniacal em relação ao nitrogênio total. O baixo valor de nitrogênio amoniacal encontrado nas silagens indica uma baixa degradação dos compostos protéicos pelas enzimas proteolíticas que são secretadas, especialmente, pelas bactérias do gênero Clostridium. Os valores de $\mathrm{pH}$ relativamente baixos podem ter auxiliado na prevenção do desenvolvimento de bactérias do gênero Clostridium, que estão entre os principais microrganismos deterioradores das silagens. De acordo com Ávila et al. (2003), assim que a forragem é cortada, a proteólise se inicia e continua durante a ensilagem, e sua extensão depende largamente da rapidez com que as condições ácidas sejam estabelecidas. A silagem da planta inteira, que teve $\mathrm{pH}$ mais elevado (Tabela 2), também apresentou maior valor de nitrogênio amoniacal em relação às silagens do terço superior e das sobras do plantio.

Os valores de densidade das silagens estão na margem citada por Ruppel et al. (1995), que é de $550-850 \mathrm{~kg} / \mathrm{m}^{3}$. As densidades das silagens foram satisafatórias para uma boa fermentação da massa, pois, segundo Holmes \& Muck (1999), as silagens devem apresentar um valor mínimo de densidade de $225 \mathrm{~kg} / \mathrm{m}^{3}$.

Segundo McDonald et al. (1991), as silagens que são confeccionadas com baixa densidade apresentam maior quantidade de ar residual na massa, o que acarreta maior período de respiração (liberação de $\mathrm{CO}_{2}$ e perda de matéria seca), maior consumo de carboidratos solúveis, redução na velocidade de produção de ácidos orgânicos e maior valor final de $\mathrm{pH}$.

Os maiores valores de $\mathrm{pH}$, nitrogênio amoniacal e densidade das silagens da fração planta inteira, podem estar correlacionados com a menor relação folha/caule $(0,31 \times 0,54$ para sobras do plantio e 0,69 para o terço superior) apresentada por esta fração da planta.

A interação de variedades com frações da parte aérea não foi significativa $(\mathrm{P}>0,05)$ para os teores de ácido lático, ácido acético, ácido propiônico e ácido butírico das silagens. Também não houve efeito significativo $(\mathrm{P}>0,05)$ de variedade sobre os teores de ácidos orgânicos das silagens (Tabela 3).

Houve diferença $(\mathrm{P}<0,05)$ entre os percentuais de ácido lático das silagens das diferentes frações da parte aérea (Tabela 4), sendo que as silagens das frações do terço superior e das sobras do plantio apresentaram médias superiores à fração planta inteira. Para os percentuais de ácido acético, ácido propiônico e ácido butírico das silagens das diferentes frações da parte aérea não houve diferença significativa (Tabela 4).

Quando comparadas à silagem de milho, considerada silagem padrão (Henrique et al., 1998), as silagens dessas variedades de mandioca e de suas frações da parte aérea apresentam valor de ácido lático superior ao relatado por Valadares Filho et al. (2006) para silagem de milho (4,93\% de ácido lático na matéria seca). De acordo com Siqueira et al. (2007), no processo fermentativo de uma silagem dá-se maior importância aos maiores teores de ácido lático, pois este é um ácido forte, sendo responsável pela redução do

Tabela 3 - Teores de ácidos orgânicos das silagens de quatro variedades de mandioca, cultivadas no Norte de Minas Gerais, após 56 dias de ensilagem (\%MS)

\begin{tabular}{lcccc}
\hline Variedade & Ácido lático & Ácido acético & Ácido propiônico & Ácido butírico \\
\hline Amarelinha & $8,19 \mathrm{a}$ & $1,0642 \mathrm{a}$ & $0,0133 \mathrm{a}$ & $0,0025 \mathrm{a}$ \\
Olho Roxo & $7,59 \mathrm{a}$ & $1,0533 \mathrm{a}$ & $0,0125 \mathrm{a}$ & $0,00 \mathrm{a}$ \\
Periquita & $9,12 \mathrm{a}$ & $1,0025 \mathrm{a}$ & $0,0075 \mathrm{a}$ & $0,00 \mathrm{a}$ \\
Sabará & $7,99 \mathrm{a}$ & $1,2358 \mathrm{a}$ & $0,0067 \mathrm{a}$ & $0,00 \mathrm{a}$ \\
$\mathrm{CV}^{1}(\%)$ & 16,77 & 13,07 & 0,79 & 0,00 \\
\hline
\end{tabular}

*Médias seguidas de mesma letra na coluna não diferem entre si pelo teste de Scott-Knott (1974) a 5\%. CV = coeficiente de variação.

Tabela 4 - Teores de ácidos orgânicos das silagens de três frações da parte aérea de quatro variedades de mandioca, cultivadas no Norte de Minas Gerais, após 56 dias de ensilagem (\%MS)

\begin{tabular}{lccc}
\hline Variedade & Ácido lático & Ácido acético & Ácido propiônico \\
\hline Planta inteira & $6,66 \mathrm{~b}$ & $1,1106 \mathrm{a}$ & $0,0125 \mathrm{a}$ \\
Sobras plantio & $8,60 \mathrm{a}$ & $1,15 \mathrm{a}$ & $0,0094 \mathrm{a}$ \\
Terço superior & $9,40 \mathrm{a}$ & $1,0063 \mathrm{a}$ & $0,00 \mathrm{a}$ \\
CV $(\%)$ & 16,77 & 13,07 & $0,00 \mathrm{a}$ \\
\hline
\end{tabular}

*Médias seguidas de mesma letra na coluna, não diferem entre si pelo teste de Scott-Knott (1974) a 5\%. CV = coeficiente de variação. 
pH da silagem para a faixa de 3,8 a 4,2, o que possibilita uma boa conservação da massa ensilada, garantindo qualidade ao produto. Segundo McDonald et al. (1991), silagens com adequada fermentação apresentam valores de ácido lático iguais ou superiores a 5,0\% da matéria seca. Tendo as silagens avaliadas neste estudo apresentado valores de ácido lático superiores a 5,0\%, pode-se inferir que estas passaram por uma adequada fermentação.

Os maiores valores de ácido lático encontrados nas silagens das frações terço superior e sobras do plantio, em relação à fração da planta inteira, explicam os menores valores de $\mathrm{pH}$ encontrados nas silagens destas duas frações.

Não houve a presença de ácido butírico nas silagens. Observou-se a presença deste ácido apenas na silagem do terço superior da variedade Amarelinha, mesmo assim em quantidade muito inferior àquela recomendada para uma silagem de ótima qualidade, que segundo Tomich et al. (2003), é de no máximo 0,09\% na matéria seca (Tabelas 3 e 4). De acordo com McDonald et al. (1991), a presença de ácido butírico em proporções iguais ou superiores a $0,1 \%$ é um indicativo de que houve fermentação indesejável durante a ensilagem, podendo desta forma ocorrer perdas na qualidade do produto final. Os valores de ácido butírico encontrados nesse estudo podem estar correlacionados com a baixa presença de nitrogênio amoniacal nas silagens, e à baixa perda por gases.

Comparando os valores de ácido propiônico encontrados nas silagens deste estudo com os valores relatados por Valadares Filho et al. (2006), para a silagem da parte aérea da mandioca e para a silagem da pare aérea da mandioca emurchecida, que são de respectivamente, 0,07 e 0,11\% da matéria seca, verifica-se que os valores encontrados nesse estudo são muito inferiores.

Os percentuais de ácido acético encontrados nas silagens deste estudo ficaram pouco acima do recomendado por McDonald et al. (1991), que é de até 0,8\% de ácido acético na matéria seca, no entanto se enquadra como uma silagem bem fermentada de acordo com a classificação de Tomich et al. (2003), sendo que estes autores consideram que uma silagem foi bem fermentada, quando esta apresenta no máximo 3,5\% de ácido acético na matéria seca. O aparecimento de ácido acético nas silagens pode ter ocorrido devido a uma eventual presença de bactérias heteroláticas na massa ensilada, estas, além de produzirem o ácido lático, também produzem o ácido acético (McDonald et al., 1991). O ácido acético também conserva bem a massa ensilada, no entanto, quando presente em concentrações acima de $0,8 \%$ é um indicativo de que houve alterações indesejáveis no processo de ensilagem. A única silagem que apresentou um teor de ácido acético abaixo de $0,8 \%$ foi a silagem do terço superior da variedade Amarelinha. Mesmo tendo apresentado valor de ácido acético dentro dos parâmetros recomendados por Tomich et al. (2003), as silagens deste estudo apresentaram médias superiores às relatadas por Valadares Filho et al. (2006), para a silagem da parte aérea da mandioca e para a silagem da parte aérea da mandioca emurchecida, que correspondem, respectivamente, a 0,23 e 0,33\% de ácido acético na matéria seca.

As perdas por efluentes foram influenciadas pelos efeitos de variedade, fração da parte aérea e dia de abertura após a confecção das silagens (Figura 1).

Foi observado efeito linear positivo para a perda por efluentes nas silagens das diferentes frações da parte aérea das quatro variedades estudadas, em função dos dias de abertura dos silos. As perdas por efluentes das silagens deste estudo, apresentaram variação marginal de $0,1518 \mathrm{~kg} / \mathrm{t}$ de massa verde ensilada, a cada dia após a ensilagem. Essa perda crescente por efluentes pode indicar que a estabilização do processo fermentativo não foi alcançada no período avaliado.

Ao se comparar as perdas por efluente das silagens avaliadas nesse estudo, com as silagens do capim Marandu, elaboradas por Ribeiro et al. (2009), que apresentaram perdas por efluente variando de 11,5 a $25,3 \mathrm{~kg} / \mathrm{t}$ de massa verde, nota-se que essas foram relativamente pequenas. As silagens da cana-de-açúcar elaboradas por Siqueira et al. (2007), apresentaram em média perdas por efluente na ordem de 58,15 kg/t de massa verde. Segundo Pupo (2002), as perdas por efluente podem chegar a $150 \mathrm{~kg} / \mathrm{t}$ de massa verde, ocorrendo, na maioria dos casos, perdas de cerca de $60 \mathrm{~kg} / \mathrm{t} \mathrm{de}$ massa verde ensilada. Essas perdas por efluente podem ser

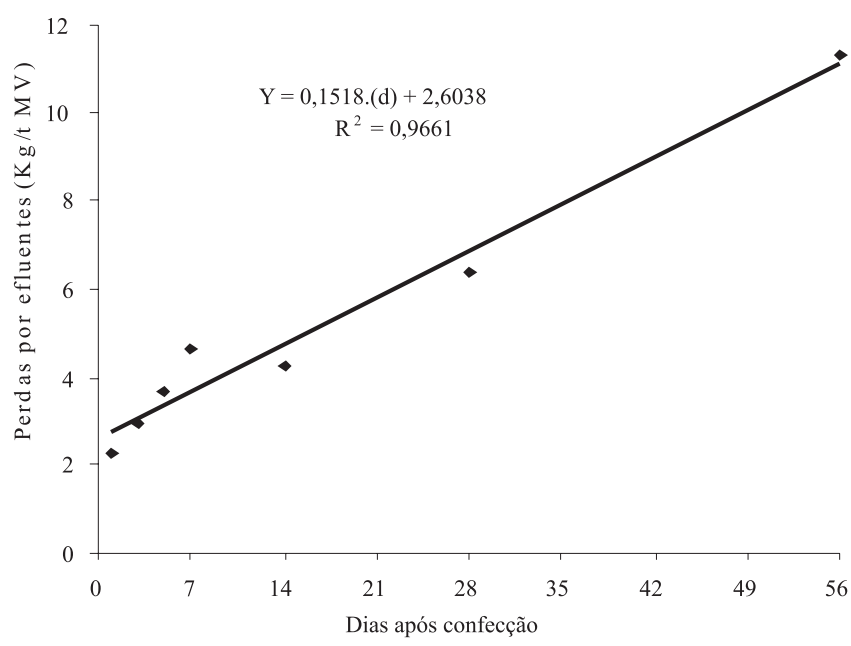

Figura 1 - Perdas por efluentes (kg/t massa verde) das silagens da parte aérea de quatro variedades de mandioca, em função dos dias de abertura após a confecção das silagens. 
reduzidas, segundo McDonald et al. (1991), com a ensilagem de materiais com no máximo 70\% de umidade. As perdas por efluente, relativamente baixas, indicam que a forragem fresca, destas variedades de mandioca, pode ser ensilada mesmo apresentando percentuais de matéria seca abaixo do desejável, que seria de 28 a 35\% de matéria seca (McDonald et al., 1991).

Quanto à perda de matéria seca por gases, houve efeito significativo dos efeitos isolados de variedade $(\mathrm{P}<0,05)$, fração da parte aérea $(\mathrm{P}<0,01)$ e dia de abertura após a confecção das silagens $(\mathrm{P}<0,01)$ (Figura 2$)$.

Foi observado efeito linear positivo para a perda de matéria seca por gases (Figura 2) nas silagens avaliadas, em função dos dias após a ensilagem. As perdas por gases das silagens deste estudo apresentaram variação marginal de 0,0169\% em porcentagem da matéria seca inicial, a cada dia após a ensilagem, em função do processo de fermentação. Esse resultado também pode sugerir maior demora para estabilização da fermentação das silagens avaliadas.

A crescente taxa de perda por gases no início da ensilagem deve-se, principalmente, à elevada atividade respiratória inicial da planta ensilada juntamente com o desenvolvimento inicial das colônias de microorganismos fermentadores. Ao passar dos dias, acontece a diminuição desta taxa de perda por gases, em virtude da estabilização da atividade microbiana no interior da massa ensilada e à diminuição da atividade respiratória do material ensilado (Jobim et al., 2007).

As silagens deste estudo apresentaram uma perda por gases considerada baixa, segundo os parâmetros relatados por Pupo (2002), em que as perdas gasosas podem atingir

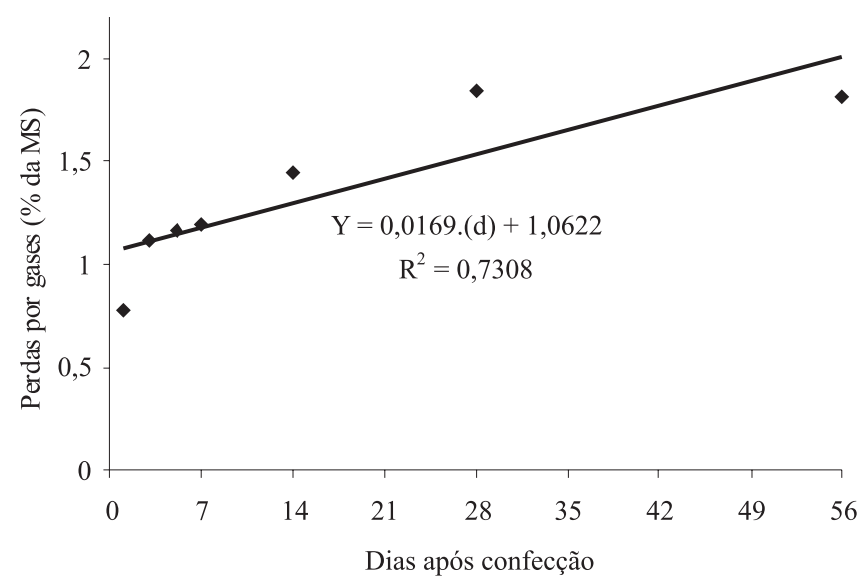

Figura 2 - Perdas de matéria seca por gases (\% da MS inicial) das silagens da parte aérea de quatro variedades de mandioca, em função dos dias de abertura após a confecção das silagens. de 2 a 5\% da matéria seca inicial. As silagens deste estudo não atingiram 2\% de perda de matéria seca inicial por gases.

Segundo Jobim et al. (2007), a baixa perda por gases pode ser ocasionada pela baixa manifestação de bactérias do gênero Clostridium, que ao atuarem, sobre o lactato ou sobre os açúcares, produzem ácido butírico e $\mathrm{CO}_{2}$.

As perdas de matéria seca por gases das silagens deste estudo foram baixas se comparadas às de silagens do capim-marandu elaboradas por Ribeiro et al. (2009), cujas perdas variaram de 0,6 a 8,6\% da matéria seca inicial, e com as silagens da cana-de-açúcar elaboradas por Siqueira et al. (2007), que apresentaram, em média, perdas por gases de $11,8 \%$ da matéria seca inicial. Entretanto, foram similares aos valores verificados por Oliveira et al. (2009), que trabalharam com silagem de capim-tanzânia e encontraram perdas por gases variáveis de 1,27 a 4,18\% da matéria seca inicial.

Não houve efeito significativo $(\mathrm{P}>0,05)$ para as variedades e as frações da parte aérea utilizadas nem interação das variedades com as frações da parte aérea sobre os índices de recuperação de matéria seca (RMS) das silagens após 56 dias de ensilagem. O índice de recuperação de matéria seca encontrado neste estudo foi elevado, com média de 99,08\%.

Os valores relativamente altos de recuperação da matéria seca obtidos neste estudo podem estar correlacionados à baixa perda por gases, que, segundo Pedroso et al. (2005), pode representar até $98,4 \%$ da perda de matéria seca, principalmente pela fermentação indesejável, em que há a formação de $\mathrm{CO}_{2}$. Além da perda por efluentes ter sido considerada relativamente baixa. Outro fator que pode ter contribuído para valores mais altos de recuperação de matéria seca foi a menor precisão da metodologia utilizada na determinação desta variável.

Siqueira et al. (2007) relacionaram uma média de recuperação de MS de 77,90\% para as silagens da cana-deaçúcar tratadas com aditivos químicos e bacterianos. As silagens avaliadas neste estudo ainda apresentaram valores de recuperação de MS superiores ao relatado por Ribeiro et al. (2009), que teve média de 95,50\% de recuperação MS nas silagens de capim-marandu tratadas com absorventes de umidade e aditivos químicos e microbianos.

\section{Conclusões}

As silagens das frações terço superior e sobras do plantio das quatro variedades de mandioca apresentam ótima qualidade fermentativa e baixa perda de matéria seca, portanto, são indicadas para o processo de ensilagem. 


\section{Agradecimentos}

À FAPEMIG, pelo apoio financeiro e auxílio com bolsas; Ao CNPq, pelo auxílio com bolsa.

\section{Referências}

ARAÚJO, M.J.; MEDEIROS, A.N.; CARVALHO, F.F. et al. Consumo e digestibilidade dos nutrientes em cabras Moxotó recebendo dietas com diferentes níveis de maniçoba. Revista Brasileira de Zootecnia, v.38, n.6, p.1088-1095, 2009.

ÁVILA, C.L.S.; PINTO, J.C.; EVANGELISTA, A.R. et al. Perfil de fermentação das silagens de capim-tanzânia com aditivos: teores de nitrogênio amoniacal e pH. Ciência e Agrotecnologia, v.27, n.5, p.1144-1151, 2003.

AZEVEDO, E.B.; NÖRNBERG, J.L.; KESSLER, J.D. et al. Silagem da parte aérea de cultivares de mandioca. Ciência Rural, v.36, n.6, p.1902-1908, 2006.

CARVAlho, G.G.P.; GARCIA, R.; PIRES, A.J.V. et al. Características fermentativas de silagens de capim-elefante emurchecido ou com adição de farelo de cacau. Arquivo Brasileiro de Medicina Veterinária e Zootecnia, v.60, n.1, p.234-242, 2008.

FOOD AND AGRICULTURE ORGANIZATION - FAO. Food and Agriculture Organization of the United Nations. Disponível em: <http://www.faostat.fao.org>. Acesso em: 11 jan. 2007.

FAUSTINO, J.O. Efeito da ensilagem do terço superior da rama de mandioca triturada ou inteira e dos tempos de armazenamento. Acta Scientiarum.Animal Sciences, v.25, n.2, p.403-410, 2003.

FERREIRA, G.D.G.; OLIVEIRA, R.L.; CARDOSO, E.C. et al. Valor nutritivo de co-produtos da mandioca. Revista Brasileira de Saúde e Produção Animal, v.8, n.4, p.364-374, 2007.

GUEDES, P.L.C.; LEMOS, P.F.B.A.; ALBUQUERQUE, R.P.F. et al. Produção de forragem de mandioca para alimentação de bovinos leiteiros no agreste paraibano. Tecnologia e Ciência Agropecuária, v.1, n.2, p.53-59, 2007.

HENRIQUE, W.; ANDRADE, J.B.; SAMPAIO. A.A.M. Silagem de milho, sorgo, girassol e suas consorciações. II. Composição bromatológica. In: REUNIÃO ANUAL DA SOCIEDADE BRASILEIRA DE ZOTECNIA, 35., 1998, Botucatu. Anais... Botucatu: SBZ, 1998. p.379-381.

HOLMES, B.J.; MUCK, R.E. Factors affecting bunker silo densities. 1999. 7p. Disponível em: <http://www.uwex.edu/ ces/crops/uwforage/BunkDens3.PDF>. Acesso em: 20 mar. 2009.

INSTITUTO BRASILEIRO DE GEOGRAFIA E ESTATÍSTICA IBGE. 2008. Disponível em: <http://www.ibge.gov.br/home/ estatistica/indicadores/agropecuaria/lspa/lspa_200810_5.shtm>. Acesso em: 24 nov. 2008.

JOBIM, C.C.; NUSSIO, L.G.; REIS, R.A.; SCHMIDT, P. Avanços metodológicos na avaliação da qualidade de forragem conservada. Revista Brasileira de Zootecnia, v.36, p.101-119, 2007 (supl. especial).

MARI, L.J. Intervalo entre cortes em capim-marandu (Brachiaria brizantha (Hochst ex. A.Rich.) Stapf cv.
Marandu): produção valor nutritivo e perdas associadas à fermentação da silagem. 159f. 2003. Dissertação (Mestrado em Agronomia) - Escola Superior Agrícola "Luiz de Queiroz", Universidade de São Paulo, Piracicaba.

McDONALD, P.; HENDERSON, A.R.; HERON, S.J.E. The biochemistry of silage. 2.ed. Marlow. Chalcombe Publications, 1991. 226p.

MODESTO, E.C.; SANTOS, G.T.; VILELA, D. et al. Caracterização químico-bromatológica da silagem do terço superior da rama de mandioca. Acta Scientiarum, v.26, n.1, p.137-146, 2004.

MODESTO, E.C.; SANTOS, G.T.; ZAMBOM, M.A. et al. Consumo, digestibilidade e parâmetros ruminais em vacas gestantes alimentadas com silagem de rama de mandioca. Revista Brasileira de Zootecnia, v.37, n.5, p.944-950, 2008.

NOGUEIRA, F.D.; GOMES, J.C. Mandioca. In: RIBEIRO, A.C. et al. (Eds.) Recomendações para o uso de corretivos e fertilizantes em Minas Gerais - $5^{\text {a }}$ Aproximação. Viçosa, MG. 1999. p.312-313.

NUNES IRMÃO, J.; FIGUEIREDO, M.P.; PEREIRA, L.G.R. et al. Composição química do feno da parte aérea da mandioca em diferentes idades de corte. Revista Brasileira de Saúde e Produção Animal, v.9, n.1, p.158-169, 2008.

OLIVEIRA, H.C.; PIRES, A.J.V.; OLIVEIRA, A.C. et al. Perdas e valor nutritivo da silagem de capim-tanzânia com uréia. Archivos de Zootecnia, v.58, n.2, p.195-202, 2009.

OLIVEIRA, J.P. Composição química e consumo voluntário do feno e da silagem da parte aérea da mandioca (Manihot esculenta Crantz). Ciência e Prática, v.8, n.2, p.203-213, 1984.

PEDROSO, A.F.; NUSSIO, L.G; PAZIANI, S.F. et al. Fermentation and epiphytic microflora dynamics in sugar cane silage. Scientia Agricola, v.62, p.427-432, 2005.

PUPO, N.I.H. Manual de pastagens e forrageiras: formação, conservação, utilização. Campinas: Instituto Campineiro de Ensino Agrícola, 2002. p.274-303.

RIBEIRO, J.L.; NUSSIO, L.G.; MOURÃO, G.B. et al. Efeitos de absorventes de umidade e de aditivos químicos e microbianos sobre o valor nutritivo, o perfil fermentativo e as perdas em silagens de capim-marandu. Revista Brasileira de Zootecnia, v.38, n.2, p.230-239, 2009.

RIBEIRO JÚNIOR, J.I. SAEG - Sistema para análises estatísticas e genética, versão 8.0. Viçosa, MG: Fundação Arthur Bernardes, 2001. 301p.

RUPPEL, K.A.; PITT, R.E.; CHASE, L.E. et al. Bunker silo management and its relationship to forage preservation on dairy farms. Journal of Dairy Science, v.78, n.1, p.141-153, 1995.

SILVA, D.J.; QUEIROZ, A.C. Análise de alimentos: métodos químicos e biológicos. 3.ed. Viçosa, MG: UFV, 2006. 235p.

SIQUEIRA, G.R.; REIS, R.A.; SCHOCKEN-ITURRINO, R.P. et al. Perdas de silagens de cana-de-açúcar tratadas com aditivos químicos e bacterianos. Revista Brasileira de Zootecnia, v.36, n.6, p.2000-2009, 2007 (supl.).

TOMICH, T.R.; PEREIRA, L.G.R.; GONÇALVES, L.C. et al. Características químicas para avaliação do processo fermentativo: uma proposta para qualificação da fermentação. Corumbá: Embrapa Pantanal, 2003. 20p. (Documentos, 57).

VALADARES FILHO, S.C.; MAGALHÃES, K.A.; ROCHA JÚNIOR, V.R. et al. Tabelas brasileiras de composição de alimentos para bovinos. 2.ed. Viçosa, MG: UFV, DZO, 2006. 329p. 